\title{
PERCEIVED RISK ANALYSIS OF AND WILLINGNESS TO BUY FOOD NANOTECHNOLOGY
}

\author{
Citra Fidyani*)1, Arif Satria**), and Kirbrandoko***) \\ *) PT Ajinomoto Indonesia \\ Jl Laksda Yos Sudarso 77-78, Sunter, North Jakarta 14350 \\ ${ }^{* *}$ Department of Communication Science and Community Development, Faculty of Human Ecology, IPB University \\ Jl. Kamper, IPB Dramaga Campus Bogor 16680 \\ ${ }^{* * *}$ Ibn Khaldun University \\ Jl. K.H. Sholeh Iskandar Km. 2 Bogor 16162
}

\begin{abstract}
A number of studies stated that nanotechnology is predicted to encourage the third wave of research diffusion, development, and advancement in agricultural and food sectors, as an integrated part of the nanotechnology revolution in various fields. The aim of this study was to assess the effect of nanotechnology knowledge, trust, and communication media on perceived risk and willingness to buy food nanotechnology. The data came from an online questionnaire with 302 people collected by an online survey, and the research used a purposive sampling method, and structural equation modeling was used for data analysis. Based on the result of the research on three variables (nanotechnology knowledge, trust, and communication media), it is known that communication media and trust had significant effects on risk perception; however, nanotechnology knowledge had no significant effect. Furthermore, perceived risk had a significant effect on willingness to buy food nanotechnology. The sequence from the largest to the smallest of willingness to buy is functional food with a health benefit, food packaging, and food additive to improved product quality. Functional food has been chosen because there is an additional health benefit they will get. Meanwhile, food packaging was considered less risky as it did not directly contact with the product and was not digested by the body. Food additives to improve product quality was the lowest since the respondents felt they did not get any benefits from the application.
\end{abstract}

Keywords: communication media, nanotechnology knowledge, perceived risk, trust, willingness to buy

\begin{abstract}
Abstrak: Sejumlah studi menyebutkan bahwa nanoteknologi diprediksi akan mendorong gelombang ketiga difusi penelitian, pengembangan dan kemajuan di sektor pertanian dan pangan, sebagai bagian yang tak terpisahkan dari revolusi nanoteknologi di berbagai bidang. Tujuan penelitian ini adalah menganalisis pengaruh nanotechnology knowledge, trust, dan media komunikasi terhadap persepsi risiko dan willingness to buy pangan nanoteknologi, Pengambilan data menggunakan media kuesioner online dengan responden sebanyak 302 orang yang dikumpulkan dengan metode purposive sampling dan metode structural equation modeling (SEM) untuk menganalisa data. Berdasarkan hasil penelitian dengan tiga variabel yaitu nanotechnology knowledge, trust, dan media komunikasi, diketahui bahwa variabel media komunikasi dan trust memberikan hasil pengaruh secara signifikan terhadap persepsi risiko. Sementara itu, nanotechnology knowledge tidak berpengaruh secara signifikan terhadap persepsi risiko. Lebih lanjut, hasil menunjukkan persepsi risiko berpengaruh secara signifikan terhadap willingness to buy pangan nanoteknologi. Jika dikelompokkan berdasarkan jenis maka urutan willingness to buy terbesar hingga terkecil adalah pangan fungsional dengan manfaat kesehatan, kemasan pangan, dan bahan tambahan pangan untuk memperbaiki kualitas produk. Pangan fungsional dipilih responden dengan alasan adanya tambahan manfaat akan kesehatan. Kemasan pangan dengan aplikasi nanoteknologi dinilai lebih tidak berisiko dikarenakan tidak kontak secara langsung dengan produk dan tidak dicerna di dalam tubuh. Sedangkan bahan tambahan pangan untuk memperbaiki kualitas produk menjadi urutan terendah dikarenakan responden merasa tidak mendapatkan manfaat apapun dari aplikasi tersebut.
\end{abstract}

Kata kunci: media komunikasi, nanotechnology knowledge, persepsi risiko, trust, willingness to buy

${ }^{1}$ Corresponding author:

Email: fidyanicitra@gmail.com 


\section{INTRODUCTION}

The Indonesian food sector in current and future time has been facing several challenges. In the agricultural sector as the main source of food, there has been a decrease in the quantity and quality of agricultural land resources, seed and nurseries that have not been optimized, inadequate infrastructure and facilities, limited agricultural human resources, poor funding and farmer institutions, and conventional technology. Meanwhile, the main challenges to Indonesian current and future agricultural development are increased productivity, production efficiency, added value and competitiveness of agricultural products. To solve the problems and challenges of agricultural development, comprehensive solution, paradigm and visionary steps are needed, such as technological innovations that can be applied to upstream-downstream aspects of agriculture and food. Nanotechnology is one of the new technology applications that offer some alternative solutions for certain problems and challenges of agricultural development.

Nanotechnology can be defined as science and technology regarding the process, manipulation, manufacturing and or application of a material structure in which one or more dimensions are 1-100 nanometers (nm) (Chaudhry and Castle, 2011; Garcia et al. 2010; Quintanilla-Carvajal etal.2010). In mathematics, $1 \mathrm{~nm}$ is equal to 1 per 1,000,000,000 meters. In the agribusiness sector, the use of nanotechnology in all phases of the food cycle has the potential to revolutionize this sector through increasing supply, quality and food safety. Nanotechnology applications in food can improve texture, taste, and aroma, prolong shelf life, increase the efficiency and effectiveness of nutrients, and use packaging materials that can extend shelf life so that they may reduce the use of preservatives and improve food safety by indicating whether food is contaminated or not.

The potential benefits of food nanotechnology continue to be promising, while concerns and potential risks, which include the potential for nanoparticle toxicity, are not well understood. This concern is reinforced by the lack of scientific consensus on the safety and environmental risks of nanotechnology which mainly came from the lack of appropriate toxicity tests that cause inadequate risk assessment of food nanotechnology. For example, in nanotechnology for food packaging, aside from some possibilities on migrating nanoparticles into food products and finally into the human body, another potential risk to be concerned is about what will happen with nanoparticles after those packaging becomes waste. In case of nanoparticles of the packaging may not be degraded, they might accumulate, interact, and endanger other ecological components.

The issue of consumer attitudes towards nanofood products was first approached by Siegrist et al. (2007), who investigated the relationship between the willingness to buy four kinds of nanofoods and the perceived benefits and risks for a sample of Swiss consumers. Subsequently, Siegrist (2008) identified the main factors influencing public acceptance of innovative foods, distinguishing between factors related to the products, in terms of perceived risks and benefits; trust and social norms; psychological factors, such as food neophobia, environmental attitudes and personal importance of naturalness. Since then, studies have estimated the relationship between these factors and consumer's willingness to buy different nanofoods in Switzerland (Siegrist et al. 2008, Stampfli et al. 2010) and in Mexico (Lopez-Vazquez et al. 2012). Bieberstein et al. (2013) evaluated the willingness to pay for nanofoods in France and Germany, focusing on the influence of information on consumer choices. Schnettler et al. (2013) studied the acceptance of nanofoods in southern Chile, taking into account the role of brand and personal level of satisfaction with food-related lifestyles.

The success of food nanotechnology application and commercialization depends on the perception and acceptance of the community on new technologies and its product application. Therefore, it is important to conduct research on community perceptions and factors that influence people's attitudes towards nanotechnology (Siegrist et al. 2010).

It should be noted that these studies are mostly carried out in developed countries, especially in the USA and in Europe, which started developing nanotechnology earlier. Indonesia has abundant natural sources of agricultural and food, and it is in the middle of the development of food nanotechnology applications and lacks information about the safety of these products; therefore, it is very interesting to know the perception of Indonesian people on nanotechnology products. Through this, the willingness of consumers to buy and the success of the technology market can be identified. The objective to be achieved from the research are: 1) 
to analyze the effect of nanotechnology knowledge, trust, and communication media on perceived risk, 2) to analyze the effect of perceived risk on the willingness to buy food nanotechnology. The scope of this study was limited to the study of the effect of nanotechnology knowledge, trust, and communication media on perceived risk and willingness to buy a number of applications for food nanotechnology products.

\section{METHODS}

This study used quantitative data to obtain primary data by conducting surveys and using online questionnaires. The secondary data were obtained from literature studies, scientific journals, and previous results relevant to the object or problems being examined. An online questionnaire was created in Google Docs with link. The link was distributed to the respondents through email application which aims to simplify and accelerate the questionnaire distribution. Data collection through questionnaires was conducted at Jabodetabek and the research was conducted from June to August 2018.

This research had unknown number of population and the sampling size was not possible to be determined by mathematical formula. In multivariate analysis, the sample size was suggested to be 10 times or more than the research variable number (Sekaran, 2011). Determination of sample size was based on Hair et al. (1995) i.e. number of samples was 5-10 times the number of indicators, and added the number of latent variables. The number of samples of this research was 302 people taken by purposive sampling technique with some specific criteria. The criteria included the respondents who answered: 1) 'yes' and 'maybe' on the question 'have you ever read or at least heard about nanotechnology?' and 2) other than 'don't know' on the question 'how do you measure your understanding about nanotechnology?'. The number of received data reached up more than 300 data items which were screened by those criteria and the final number data to be analyzed was 302 .

The analytical method used was Structural Equation Modeling (SEM). SEM analysis is used in searching for causal relationship that can measure relationships that are unable to be measured directly or so-called latent variables. Measuring them requires an approach through measurement of other influencing factors, and they can be measured or called as indicator variables.
The causality relationship is depicted in path diagram to show the flow of relationship between endogenous and exogenous variables. The development of the path diagram in the research determines the effect of nanotechnology knowledge, communication media, and trust on perceived risk, and the effect of perceived risk on willingness to buy. The variables used in this research were 5 latent variables ( 1 endogenous variable and 4 exogenous latent variables). Table 1 exemplifies the latent variables and their indicators in the research model.

Figure 1 is the framework of this research. Perceived analysis and willingness to buy on food nanotechnology is explained through hypotheses. The hypotheses proposed in this study as temporary answers to the structural model are as follows:

1. The effect of nanotechnology knowledge, communication media, and trust on perceived risk

Consumer knowledge related to nanotechnologybased food is worth studying because more products will be available in the future. Many highlight the fact that the public knows little about nanotechnology (McCarron, 2016). In the early stages of the problem attention cycle, where people are unfamiliar with nanotechnology, public perceptions of the benefits and risks of nanotechnology are potentially influenced by many factors, including media use, interpersonal communication, and cognitive processes (Ho et al. 2011). Due to the fact that nanotechnology is a technology that is currently being developed, where people have little knowledge, it is important that they obtain good information, and that they can trust the institutions responsible for the development and regulation of food products (McCarron, 2016).

The studies conducted by Ho (2008), Ho et al. (2011), Stampfli et al. (2010), Cobb and Macoubrie (2004) empirically proved that nanotechnology knowledge, communication media, and trust significantly effect on perceived risk. Thus the hypotheses can be put forward as follows: $\mathrm{H} 1$ : communication media significantly affects nanotechnology knowledge; H2: nanotechnology knowledge significantly affects trust; H3: communication media significantly affects trust; H4: nanotechnology knowledge significantly affects perceived risk; H5: communication media significantly affect perceived risk; and H6: trust significantly affects perceived risk. 
Table 1. Latent Variable and Indicators

\begin{tabular}{|c|c|c|}
\hline Variable & Variable Definition & Description \\
\hline \multirow{6}{*}{$\begin{array}{l}\text { Nanotechnology } \\
\text { Knowledge (X1) }\end{array}$} & \multirow{6}{*}{$\begin{array}{l}\text { Understanding and } \\
\text { knowledge related to } \\
\text { nanotechnology }\end{array}$} & Nanomaterial size $(\mathrm{X} 1.1)$ \\
\hline & & Opportunity to utilize nanotechnology (X1.2) \\
\hline & & Nanomaterial properties $(\mathrm{X} 1.3)$ \\
\hline & & Nanotechnology in food application (X1.4) \\
\hline & & Physiology of food nanotechnology (X1.5) \\
\hline & & Size of the final product using nanotechnology application (X1.6) \\
\hline \multirow{5}{*}{$\begin{array}{l}\text { Communication } \\
\text { Media (X2) }\end{array}$} & \multirow{5}{*}{$\begin{array}{l}\text { Interest and attention } \\
\text { to nanotechnology } \\
\text { content in several } \\
\text { communication } \\
\text { media }\end{array}$} & Interest and attention to printed media (X2.1) \\
\hline & & Interest and attention to television (X2.2) \\
\hline & & Interest and attention to social media (X2.3) \\
\hline & & Interest and attention to seminar/discussion/conversation (X2.4) \\
\hline & & Tendency to explore information (X2.5) \\
\hline \multirow[t]{4}{*}{ Trust (X3) } & \multirow{4}{*}{$\begin{array}{l}\text { Trust in the } \\
\text { information } \\
\text { provided regarding } \\
\text { the risk of food } \\
\text { nanotechnology }\end{array}$} & $\begin{array}{l}\text { Trust in Indonesia National Agency of Drug and Food Control (NADFC) } \\
\text { (X3.1) }\end{array}$ \\
\hline & & Trust in researchers from University (X3.2) \\
\hline & & Trust in consumer protection institutions (NGO) (X3.3) \\
\hline & & Trust in food industries/distributors (X3.4) \\
\hline \multirow{14}{*}{$\begin{array}{l}\text { Perceived Risk } \\
\text { (X4) }\end{array}$} & \multirow{14}{*}{$\begin{array}{l}\text { Assessing the } \\
\text { risk of food } \\
\text { nanotechnology } \\
\text { application }\end{array}$} & Functional Risk (XF4) \\
\hline & & Risk application in food to improve taste and texture (XF4.1) \\
\hline & & Risk application in food to increase effectiveness of nutrients (XF4.2) \\
\hline & & Risk application in food packaging to extend shelf life (XF4.3) \\
\hline & & Risk application in food packaging to indicate microbial contamination (XF4.4) \\
\hline & & Social Risk (XS4) \\
\hline & & Positive opinion/feeling towards nanotechnology (XS4.1) \\
\hline & & Having no worries about the risk of nanotechnology application (XS4.2) \\
\hline & & The risk of nanotechnology application is well controlled (XS4.3) \\
\hline & & Physical Risk (XPh) \\
\hline & & Food nanotechnology compared to conventional food (XPh4.1) \\
\hline & & Food nanotechnology compared to organic food (XPh4.2) \\
\hline & & Required specific information on the label (XPh4.3) \\
\hline & & Impact of nanotechnology on health (XPh4.4) \\
\hline \multirow{6}{*}{$\begin{array}{l}\text { Willingness to } \\
\text { buy) (Y) }\end{array}$} & \multirow{6}{*}{$\begin{array}{l}\text { Willingness to } \\
\text { buy in number } \\
\text { examples of food } \\
\text { nanotechnology } \\
\text { application }\end{array}$} & Ice cream added with nanometre-sized titanium dioxide (Y1) \\
\hline & & Salt and sugar added with nanometre-sized titanium dioxide (Y2) \\
\hline & & Fruit juice drinks added with nanometre-sized bioactive molecules (Y3) \\
\hline & & Bread added with nanometre-sized omega-3 (Y4) \\
\hline & & Plastic bottle package made of nanometre-sized polymers (Y5) \\
\hline & & Meat plastic package made of nanometre-sized silver (Y6) \\
\hline
\end{tabular}

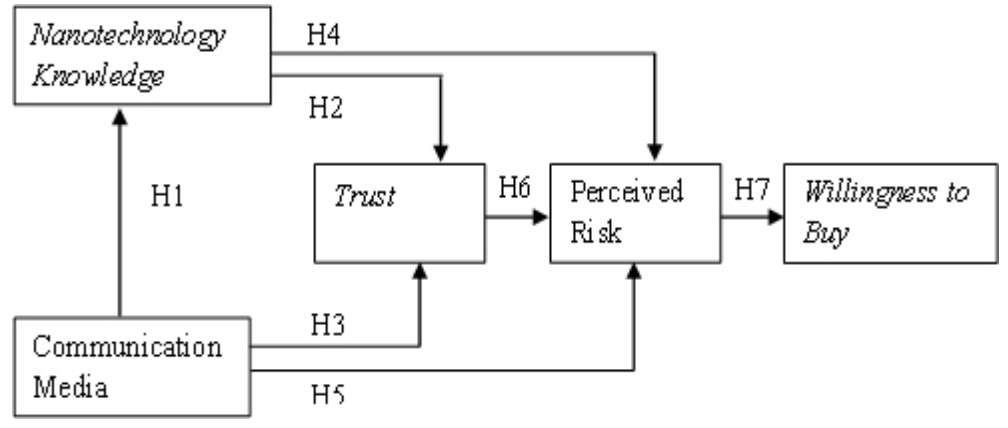

Figure 1 Research Framework 
2. The effect of perceived risk on willingness to buy

Uncertainty surrounding the introduction of nanotechnology innovations in the food sector has led to widespread scientific and social studies regarding the risks and benefits of nanotechnology applications. The more the consumers know about perceived risk of a product, the lower their willingness to buy. On the contrary, the lower the consumers know about perception of the risk of a product, the higher their desire to buy the product. Researches conducted by Fairweather (2007), Siegrist et al. (2009), Lopez-Vazquez et al. (2012) proved that perceived risk significantly affects willingness to buy food nanotechnology products. Thus, the hypotheses can be put forward as follows: H7: perceived risk significantly affects willingness to buy.

Table 2. Demographic characteristics of respondents

\begin{tabular}{|c|c|c|c|}
\hline Characteristic & Category & Number (n) & Percentage $(\%)$ \\
\hline \multirow[t]{2}{*}{ Gender } & Male & 98 & 32.5 \\
\hline & Female & 204 & 67.5 \\
\hline \multirow[t]{6}{*}{ Age (years old) } & $21-25$ & 148 & 49 \\
\hline & $26-30$ & 111 & 36.8 \\
\hline & $31-35$ & 30 & 9.9 \\
\hline & $36-40$ & 9 & 3.0 \\
\hline & $41-45$ & 2 & 0.7 \\
\hline & $46-50$ & 2 & 0.7 \\
\hline \multirow[t]{3}{*}{ Educational Level } & Graduate & 103 & 34.1 \\
\hline & Postgraduate (master) & 193 & 63.9 \\
\hline & Postgraduate (doctor) & 6 & 2.0 \\
\hline \multirow[t]{2}{*}{ Educational Background } & Science & 293 & 97.3 \\
\hline & Non-science & 9 & 3.0 \\
\hline \multirow[t]{7}{*}{ Occupation } & University student & 154 & 51.0 \\
\hline & Private company employee & 89 & 29.5 \\
\hline & Civil servant & 24 & 7.9 \\
\hline & Entrepreneur & 7 & 2.3 \\
\hline & Professional & 6 & 2.0 \\
\hline & Housewife & 11 & 3.6 \\
\hline & Others & 11 & 3.6 \\
\hline
\end{tabular}

\section{RESULTS}

\section{Demographic Characteristics of Respondents}

Table 2 explaining demographic aspects of respondents included age, gender, educational level, educational background, and occupation.

\section{Evaluation of Model Fit Level}

According to Hair et al. (1995), model fit assessment is conducted through several stages i.e. 1) overall model fit; 2) suitability of measurement model, and 3) suitability of the structural model. Based on the overall model fit assessment, this model is already qualified and has good fit. Thus, the research model can be considered feasible. 
The reliability test results indicate that the model met the requirements, indicated by the value of Variance Extracted (VE) of $>0.5$, which means the model was valid, and the value of Construction Reliability (CR) of $>0.7$, which means that each latent construct was declared as valid and reliable. The results of the structural model suitability test are shown in the SEM model in Figure 2.

\section{Contributing Indicators to Latent Variables}

The latent variables used in this research were nanotechnology knowledge, communication media, trust, perceived risk, and willingness to buy. Indicators that contribute the most to explain nanotechnology knowledge is nanotechnology application in food (X1.4). This is because the respondents have known that nanotechnology can be applied to food. As much as $98.3 \%$ of the respondents answered correctly that nanotechnology can be applied in food area. The indicators that contribute the most to explain the communication media were interest and attention to television media (X2.3). It showed that television is the media that may contribute the most in helping to multiply, duplicate, or strengthen information to be distributed into larger audience.

The indicator that contributes the most to explain trust is information from researchers/scientists from universities (X3.2). As much as $97 \%$ of respondents agreed that they believed the benefits and risks of nanotechnology applications informed by researchers/ scientists from universities. The highest indicator contributing to explain perceived risk was physical risk (XPh4). The perception of the biggest risk is reflected by physical risk where the respondents considered that the application of nanotechnology in food may have an impact on health. The biggest indicator contributing to explain willingness to buy was Y3 or nanotechnology application in fruit juice drinks added with nanometersized bioactive molecules.

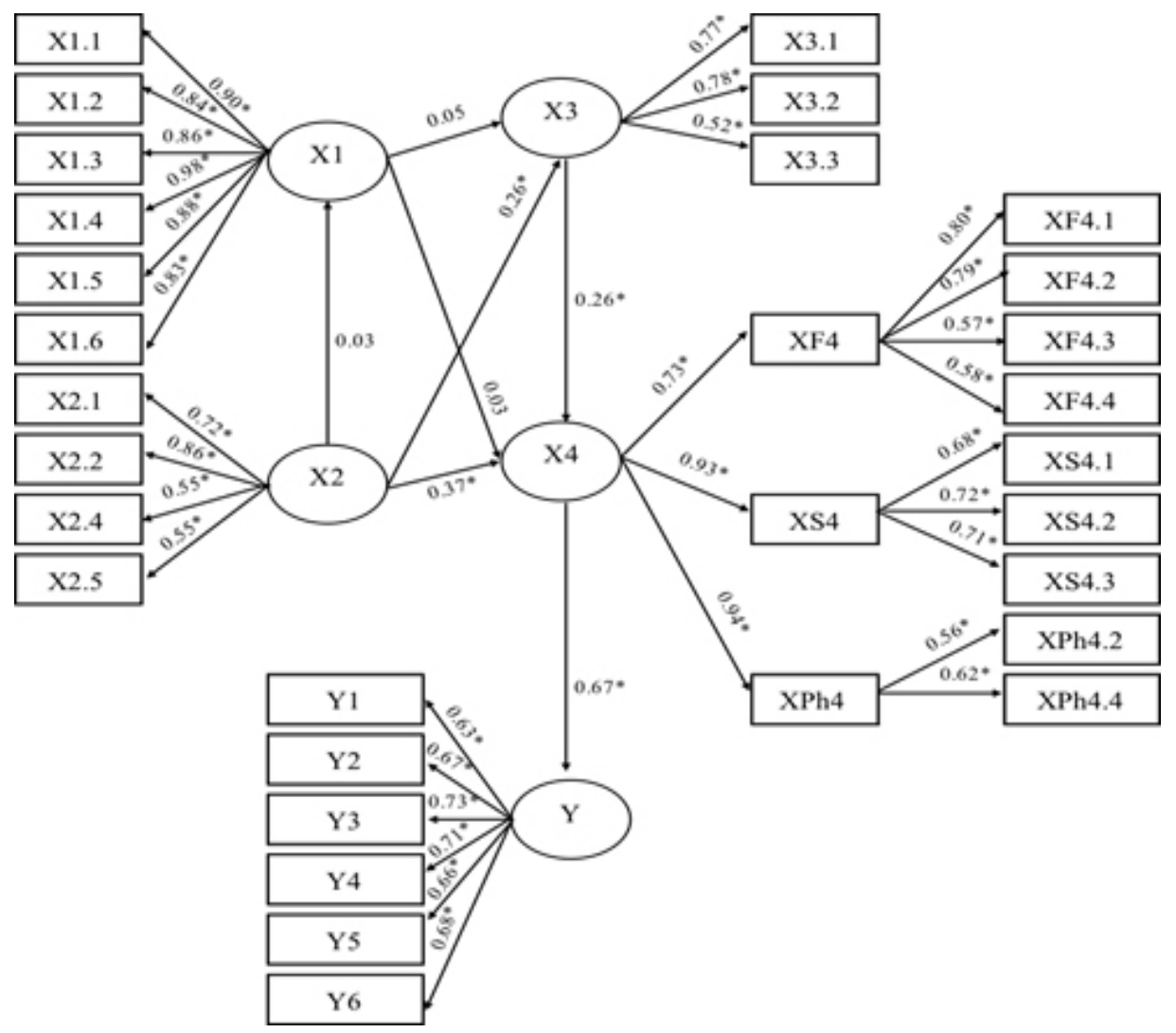

Figure 2. SEM Measurement model $\left({ }^{(*)}\right.$ categorized as significant $)$ 


\section{Hypothesis Testing}

Based on the empirical model proposed in this study, hypothesis can be tested by testing the path coefficients in the structural equation model. In the case of the value of the path coefficient $>0.05$ and the value of $t$-count $>1.96$, the effect on certain variables is considered significant. Table 3 explains in detail the estimation results of the SEM model. From the 7 hypotheses tested, there are 3 hypotheses that give insignificant results (hypotheses rejected), namely $\mathrm{H} 1, \mathrm{H} 2$, and $\mathrm{H} 4$. Meanwhile there are 4 hypotheses giving significant results (hypotheses accepted), namely, H2, H5, H6, and $\mathrm{H} 7$.

\section{The Effect of Communication Media on Nanotechnology Knowledge}

Thefirsthypothesistesting shows that the communication media have a positive but not significant effect on nanotechnology knowledge. Thus, this study rejected the first hypothesis which stated that communication media had a significant effect on nanotechnology knowledge.

Almost all respondents in this study were having science background (76.8\%), meaning that they were more familiar with the term of nanotechnology. In replying to the question about source of their knowledge of nanotechnology, 33.7\% answered they obtained it from their activities during their academic period. This explanation is supported by the research conducted by Karim et al. (2017) stating that compared to communication media, academic activities play an important role in shaping perceptions of new technologies especially nanotechnology.

Meanwhile, the percentage of other sources regarding the respondent's knowledge on nanotechnology coming from seminars/discussions, printed media, television, social media is still low i.e. approximately $10 \%-12 \%$. Align with current situation of nanotechnology issues, nanotechnology information is still in the initial stages of attention cycle, which is characterized by low information and media coverage. Communication media in Indonesia have just begun to provide information on the issue of nanotechnology; however, they provide very little information on the risk and benefit of this application. This is likely to be a reason that can explain why communication media do not significantly influence nanotechnology knowledge.

\section{The Effect of Nanotechnology Knowledge on Trust}

The second hypothesis testing shows that nanotechnology knowledge had a positive but not significant effect on trust. Thus, this study rejected the second hypothesis which stated that nanotechnology knowledge had significant effect on trust.

Almost all respondents in this study had education background in science (76.8\%). In replying to the question as to the source of their knowledge of nanotechnology, 33.7\% answered they obtained it during their academic activities. Because the respondents had a background in science and already had the knowledge gained during the academic activities, in terms of evaluating the risks and benefits of nanotechnology, trust is no longer needed. For the respondents, their background and familiarities to nanotechnology are considered to be sufficient enough to determine the risk or benefits of nanotechnology. That is why, in this case, trust was not significantly influential. This analysis is supported by previous research conducted by Siegrist and Cvetkovich (2000) providing the same results that there is no relationship between knowledge on trust and perceived risk. Trust will play a role in a condition that a person has limited knowledge.

\section{The Effect of Communication Media on Trust}

The third hypothesis testing shows that communication media had a positive and significant effect on the trust. Thus, this study accepted the third hypothesis which stated that the communication media had a significant effect on trust.

Mass media have now begun to highlight nanotechnology. Although the mass media in general provide information that is more positive, still there is imbalance information delivered between the risks and benefits of nanotechnology applications. Due to the imbalance of information on mass media, this may encourage someone's sense to entrust the risks or benefits of the application of nanotechnology to others who are considered more trustworthy (Ho, 2008). This is what can be explained that the communication media have a significant influence on trust. In addition, previous showed that interpersonal communication and social networks are able to strengthen the influence of the mass media, especially in which the public is unfamiliar enough with nanotechnology (Ho et al. 2011). Consumer confidence is not only built from 
good product quality and ease of availability, but also from appropriate communication media reaching the right target (Lisarini et al. 2018). The same analysis is also supported by previous research that has been done by Ho (2008) in which the study stated that the communication media have given significant effect on trust.

\section{The Effect of Nanotechnology Knowledge on Perceived Risk}

The fourth hypothesis testing shows that nanotechnology knowledge had a positive but not significant effect on perceived risk. Thus, this study rejected the fourth hypothesis which stated that nanotechnology knowledge had significant effect on perceived risk.

Educational background is a main factor that can shape someone's perception of a new technology. When the respondents were asked about the sources obtained by them for nanotechnology knowledge, $33.7 \%$ answered that they obtained them during the academic activities, and another source is from communication media. However, none of the respondents answered all questions correctly in the section on nanotechnology knowledge. It is interesting to know that this study shows that $76.8 \%$ of respondents knew or at least ever heard the term nanotechnology, but only $7.1 \%$ of respondents felt they had very sufficient knowledge on nanotechnology. The condition where a person does not have sufficient knowledge, they do not fully evaluate the risks and benefits of a technology application. However, they use other factors such as trust to other parties that are considered more expert (government officials/ researchers) (Sjoberg, 1998). This is likely to be one of the factors that could explain that nanotechnology knowledge has no effect on perceived risk. Siegrist and Cvetkovich (2000) research provides the same results, arguing that there is no relationship between knowledge and perceived risk.

\section{The Effect of Communication Media on Perceived Risk}

The fifth hypothesis testing shows that communication media have a positive and significant effect on perceived risk. Thus, this study accepted the fifth hypothesis which states that the communication media have a significant effect on perceived risk.

The use of media and interpersonal communication is one of the potential factors that influence public perceptions on the risks and benefits of a new technology, especially nanotechnology. Currently, nanotechnology issue is still in the early stages of attention cycle, in which the public is not familiar enough with the term and application of nanotechnology (Ho et al. 2011). The media play a highly potential role in framing consumer attitudes and acceptance of food nanotechnology applications (Siegrist, 2010). Through the help of mass media, the public is able to decide on the risks and benefits of the application of food nanotechnology (Ho et al. 2011). The similar researches which also showed that communication media had a significant effect on perceived risk were also found in Ho (2008), Ho et al. (2011), Kim et al. (2014), and Karim et al. (2017).

Table 3. Estimation Results of SEM Model

\begin{tabular}{|c|c|c|c|c|c|c|}
\hline \multicolumn{3}{|c|}{ Variables } & \multirow{2}{*}{$\begin{array}{l}\text { Path } \\
\text { Coef. } \\
0.03\end{array}$} & \multirow{2}{*}{$\begin{array}{c}\text { t-values } \\
0.50\end{array}$} & \multirow{2}{*}{$\begin{array}{c}\text { Conclusion } \\
\text { Not } \\
\text { Significant }\end{array}$} & \multirow{2}{*}{$\begin{array}{c}\text { Remarks } \\
\text { H1 is rejected }\end{array}$} \\
\hline H1: Communication Media (X2) & $\rightarrow$ & $\begin{array}{l}\text { Nanotechnology Knowledge } \\
\text { (X1) }\end{array}$ & & & & \\
\hline $\begin{array}{l}\text { H2: Nanotechnology knowledge } \\
\text { (X1) }\end{array}$ & $\rightarrow$ & Trust (X3) & 0.05 & 0.72 & $\begin{array}{l}\text { Not } \\
\text { Significant }\end{array}$ & $\mathrm{H} 2$ is rejected \\
\hline H3: Communication Media (X2) & $\rightarrow$ & Trust (X3) & 0.26 & 3.52 & Significant & $\mathrm{H} 3$ is accepted \\
\hline $\begin{array}{l}\text { H4: Nanotechnology knowledge } \\
\text { (X1) }\end{array}$ & $\rightarrow$ & Perceived Risk (X4) & 0.03 & 0.44 & $\begin{array}{l}\text { Not } \\
\text { Significant }\end{array}$ & $\mathrm{H} 4$ is rejected \\
\hline H5: Communication Media (X2) & $\rightarrow$ & Perceived Risk (X4) & 0.37 & 5.03 & Significant & H5 is accepted \\
\hline H6: Trust (X3) & $\rightarrow$ & Perceived Risk (X4) & 0.26 & 3.44 & Significant & H6 is accepted \\
\hline H7: Perceived Risk (X4) & $\rightarrow$ & Willingness to buy (Y) & 0.67 & 8.20 & Significant & $\mathrm{H} 7$ is accepted \\
\hline
\end{tabular}




\section{The Effect of Trust on Perceived Risk}

The sixth hypothesis testing shows that trust had a positive and significant effect on perceived risk. Thus, this study accepted the sixth hypothesis which stated that trust has a significant effect on perceived risk.

Siegrist and Cvetkovich (2000) stated that a person uses their trust in deciding the risk or benefit of a new technology when they do not have sufficient knowledge. The more the consumers trust researchers, consumer protection institutions, and food industries/retails, they more they are able to reduce perceived risk. When the consumers do not know the risks or benefits of products, they will only use the information issued by these parties. Therefore, trust is a factor that contributes to the acceptance of new innovations in food technology including nanotechnology (Cobb and Macoubrie, 2004). Trust is a factor that can significantly affect perceived risk. The function of trust is to reduce the complex conditions experienced by a person. In other words, someone decides the risk or benefits of nanotechnology applications not only based on the knowledge they have but also based on his or her trust on other parties that are considered more expert, trustworthy (government/ researcher) or more accurate (Earle and Cvetkovitch, 1995). The same analysis is also supported by previous research conducted by Siegrist and Cvetkovich (2000), Siegrist et al. (2008), Cobb and Macoubrie (2004), Lee et al. (2005), in which the study stated that trust had significant influence on perceived risk.

\section{The Effect of Perceived Risk on Willingness to Buy}

The seventh hypothesis testing showed that the effect of perceived risk had a positive and significant influence on willingness to buy. Thus, this study accepted the seventh hypothesis which stated that perceived risk had a significant effect on willingness to buy.

Willingness to buy nanotechnology application products in this study varies among different types of applications. The results showed that the highest willingness to buy was in the fruit juice application product added with nanometer-sized bioactive molecules. Based on the group type, the highest to the lowest willingness to buy started from functional food with health benefits, food packaging, and food additives to improved product quality. The respondents still tended to give a negative response to the application of food nanotechnology, even though the product had been completed with an explanation of its risk and benefits to consumers. However, they gave higher response to willingness to buy functional food nanotechnology applications. The same results are also supported by previous research conducted by Siegrist et al. (2009), Bech-Larsen and Scholderer (2007), Urala and Lahteenmaki (2007), Verbeke (2005), and Setiawati et al. (2018). The results stated that consumers were more willing to buy functional foods providing certain benefits to their health. In addition, Bech-Larsen and Scholderer (2007) said that consumer acceptance of functional food is mainly influenced by its claims of benefits from the product.

Nanotechnology application of food products chosen by the respondents was food packaging. Food packaging with the application of nanotechnology is considered less risky because it does not contact directly with the product and is not digested in the body. This result is in accordance with the research conducted by Siegrist et al. (2008), Lopez-Vazquez et al. (2012) which stated that food packaging would be more favored by the consumers than other applications. Nanotechnology application of food products with food additives to improve product quality was the lowest in the willingness to buy. The same result is also supported by the research conducted by Siegrist et al. (2009) arguing that the application of nanotechnology which has something to do with food additives to improve product quality gives the lowest willingness to buy, because the respondents feel that they do not get any benefits from the application.

Perceived risk is one factor that influences willingness to buy food nanotechnology. The higher the consumer's perception of the risk of a product, the lower the consumer's desire to buy, and vice versa. Numerous studies conducted by Cook and Fairweather (2007), Stampfli (2009), Tran (2015), Sodano et al. (2016) showed that perceived risk had a significant effect on willingness to buy food nanotechnology.

\section{Direct and Indirect Effects among Variables}

The path coefficient value for indirect effect of nanotechnology knowledge on perceived risk through trust was 0.05 whereas that of direct effect of nanotechnology knowledge on perceived risk was 0.03. Both of them gave the same result which is not significant. One of the theoretical foundations that supports the results of this study is Gladwell (2005) who suggested the idea of thin slicing. Thin slicing 
is the ability to use limited information from a very narrow period of experience to finally arrive at a conclusion. This idea shows that spontaneous decisions are often as good as or even better than carefully planned and considered ones. Sometimes having too much information can interfere with the accuracy of the assessment. Having lots of information in many ways can strengthen judgment but does not help make it more accurate. A better assessment can be carried out from the simplicity and efficiency of information. The result of this study is consistent with the research conducted by Siegrist and Cvetkovich (2000) which gives the same result. There is no relationship between knowledge on trust and perceived risk.

The respondents in this study were dominated by those who had background in science and were considered to have good knowledge and information on nanotechnology. However, in reality the respondents were not able to determine the perception of risk. In accordance with Gladwell (2005), in complex conditions and having a lot of information made them to be spontaneous and not use much of the information they actually had.

The results of this study are consistent with the research conducted by Siegrist and Cvetkovich (2000) which gives the same results that there is no relationship between knowledge and other variables studied i.e. the perception of risk and trust.

The path coefficient value for indirect effect of communication media on perceived risk through trust was 0.26 , while that of the direct effect communication media on perceived risk was 0.37 . Although both of them were significant, direct effect has greater path coefficient, so the effect is greater when compared to the indirect effect of communication media on perceived risk. This study gives the same result as Ho (2008) did. Communication media had significant effect on perceived risk through trust.

\section{Managerial Implication}

Food industries need to identify the benefits of nanotechnology that consumers most likely to choose. Communicate the right message to consumers before launching market products, to ensure that consumers trust the information and accept the products. Applications in food packaging and functional food are potential applications that are considered to be useful and acceptable. The government and researchers are as policy makers need to consider that the current level of consumer awareness about food nanotechnology applications is still low. The challenge faced by the government and researchers is to inform the public about the application of food nanotechnology. Labeling products with 'nano' without telling consumers about what nanotechnology is might be a negative impact on public acceptance, because it can be interpreted as a warning about potential risks. The trust in the information provided by the government as a regulator will determine public acceptance of food nanotechnology applications. Therefore, it is necessary to make risk communication, openness, and involvement with consumers.

\section{CONCLUSIONS AND RECOMMENDATIONS}

\section{Conclusions}

Based on the result, it is known that communication media and trust have significant effects on perceived risk. Meanwhile, nanotechnology knowledge has no significant effect on perceived risk. Furthermore, perceived risk has a significant effect on willingness to buy food nanotechnology. Nanotechnology knowledge does not significantly influence perceived risk. Because currently, either globally or particularly, the Indonesian are not familiar enough with the term of nanotechnology. Communication media significantly influence perceived risk, due to the use of mass media and interpersonal communication which become the potential factors in influencing public perceptions on risks and benefits of new technology, particularly, nanotechnology. Trust significantly influences perceived risk, as the function of trust is to reduce the complex condition experienced by a person.

Perceived risk which becomes the main factor for the respondents is a physical risk. The perceived risk significantly influences the willingness to buy food nanotechnology. The sequence from the largest to the smallest of willingness to buy starts from functional food with a health benefit, food packaging, and food additive to improve product quality. Functional food is chosen by the reason that there are additional health benefits they will get. Meanwhile, food packaging is considered less risky as it does not directly contact with 
the product and is not digested within the body. Food additive to improve product quality becomes the lowest since the respondents feel they do not get any benefits from the application.

\section{Recommendations}

The research may become more profound and more capable to understand the public perceptions if it is conducted throughinterviews or focus group discussions. With various limitations in this study, it is expected to be continued with the addition of other variables. For example, socio-demographic characteristics, variations in examples of nanotechnology product applications, divide the population sample into 2 groups (without and with nanotechnology knowledge), and t-test analysis between the two groups was carried out. Based on the results of the study, communication media is a factor that significantly influences perceived risk; therefore, research can be continued in terms of communication strategies.

\section{REFERENCES}

Bieberstein A, Roosen J, Marette S, Blanchemanche S, Vandermoere F. 2013. Consumer choices for nano-food and nano-packaging in France and Germany. European Review of Agricultural Economics 40(1):73-94.https://doi.org/10.1093/ erae/jbr069.

Bech-Larsen T, Scholderer J. 2007. Functional foods in Europe: consumer research, market experiences and regulatory aspect. Trends in Food Science \& Technology 18(2007): 231-234. https://doi. org/10.1016/j.tifs.2006.12.006.

Chaudhry Q, Castle L. 2011. Food applications of nanotechnologies: an overview of opportunities and challenges for developing countries. Trends in Food Science \& Technology 22(11): 595-603. https://doi.org/10.1016/j.tifs.2011.01.001.

Cobb MD, Macoubrie J. 2004. Public perceptions about nanotechnology: risk, benefits, and trust. Journal of Nanoparticle Research 6: 395-405. https://doi.org/10.1007/s11051-004-3394-4.

Cook AJ, Fairweather JR. 2007. Intentions of New Zealanders to purchase lamb or beef made using nanotechnology. British Food Journal 109(9): 675-688. https://doi. org/10.1108/00070700710780670.

Garcia M, Forbe T, Gonzales E. 2010. Potential applications of nanotechnology in the agrofood sector. Ciência e Tecnologia de Alimentos 30(3): 573-581. https://doi.org/10.1590/S010120612010000300002.

Gladwell M. 2005. Blink: The Power of Thinking Without Thinking. New York: Little, Brown and Company.

Hair JF, Anderson RE, Tatham RL, Black WC. 1995. Multivariate Data Analysis 4th Edition. Jew Jersey: Prentice Hall International.

Ho SS. 2008. Value predisposition, communication, and attitudes toward nanotechnology: the interplay of public and experts [disertation]. Madison: University of Wisncosin-Madison.

Ho SS, Scheufele DA, Corley EA. 2011. Factor influencing public risk-benefit consideration of nanotechnology: assessing the effect of mass media, interpersonal communiation, and elaborative processing. Public Understanding of Science 22(5): 606-623. https://doi. org/10.1177/0963662511417936.

Karim ME et al. 2017. Malaysian tertiary level students and their understanding knowledge perception of nanotechnology. Journal of Advanced Research in Social and Behavioural Sciences 6(1): 52-67.

Kim Y et al. 2014. Interactive survey of consumer awreness of nanotechnologies and nanoparticles inconsumerproductin South Korea.International Journal of Nanomedicine 2014(9): 11-20. https:// doi.org/10.2147/IJN.S57919.

Lee CJ, Scheufele DA, Lewenstein BV. 2005. Public attitudes toward emerging technologies: examining the interactive effects of cognitions and affect on public attitudes toward nanotechnology. Science Communication 27(2): 240-267. https:// doi.org/10.1177/1075547005281474.

Lisarini E, Yusuf E, Sutina. 2018. The effect of quality, communication and outputs of marketing channel of Cianjur pandanwangi rice on consumer trust in Java West marketing area. Indonesian Journal of Business and Entrepreneurship 4(2): 109-117. https://doi.org/10.17358/ijbe.4.2.109.

Lopez-Vazquez E, Brunner TA, Siegrist M. 2012. Perceived risk and benefits of nanotechnology applied to the food and packaging sector in Mexico. British Food Journal 114(2):197-205. https://doi.org/10.1108/00070701211202386.

McCarron E. 2016. Nanotechnology and food: investigating consumer's acceptance of food produced using nanotechnology [thesis]. Dublin: Dublin Business School. 
Quintanilla-Carvajal M et al. 2010. Nanoencapsulation: a new trend in food engineering processing. Food Engineering Reviews 2(1): 39-50. https:// doi.org/10.1007/s12393-009-9012-6.

Schnettler B et al. 2013. Food neophobia, nanotechnology and satisfaction with life. Appetite 69(1): 71-79. https://doi.org/10.1016/j. appet.2013.05.014.

Sekaran U, Bougie R. 2009. Research Methods for Business: A Skill Building Approach. New York: John Wiley and Sons.

Setiawati H, Hartoyo, Simanjuntak M. 2018. Analysis intention of purchasing organic foods by the undergraduate student of IPB using the theory of planned behaviour approach. Jurnal Manajemen \& Agribisnis 15(2): 198-207. https://doi. org/10.17358/jma.15.2.198.

Siegrist M, Cvetkovich G. 2000. Perception of hazard: the role of social trust and knowledge. Risk Analysis 20(5): 713-719. https://doi. org/10.1111/0272-4332.205064.

Siegrist $M$ et al. 2007. Public acceptance of nanotechnology foods and food packaging: the influence of affect and trust. Appetite 49(1): 459-466. https://doi.org/10.1016/j. appet.2007.03.002.

Siegrist M. 2008. Factors influencing public acceptance of innovative food technologies and products. Trends in Food Science \& Technology 17(11): 547-556. https://doi.org/10.1016/j. tifs.2008.01.017.

Siegrist M et al. 2008. Perceived risk and perceived benefits of different nanotechnology foods and nanotechnology food packaging. Appetite 51: 283-290. https://doi.org/10.1016/j. appet.2008.02.020.

Siegrist M, Stampfli N, Kastenholz H. 2009. Acceptance of nanotechnology foods: a conjoint study examining consumers willingness to buy. British Food Journal 1111(7): 660-668. https:// doi.org/10.1108/00070700910972350.

Sjoberg L. 1998. Risk Perception: Experts and The Public. European Psychologist 3(1): 1-12. https://doi.org/10.1027/1016-9040.3.1.1.

Sodano V, Gorgitano MT, Verneau F. 2016. Consumer acceptance of food nanotechnology in Italy. British Food Journal 118(3): 714-733. https:// doi.org/10.1108/BFJ-06-2015-0226.

Stampfli N, Siegrist M, Kastenholz H. 2010. Acceptance of nanotechnology in food and food packaging: a path model analysis. Journal of Risk Research 13(3): 353-365. https://doi. org/10.1080/13669870903233303.

Tran VTT. 2015. Consumer perception and labeling regimes as determinants of the market and welfare effects of food nanotechnology [disertation]. Nebraska: University of Nebraska.

Urala N, Lahteenmaki L. 2007. Consumer's Changing Attitude Towards Functional Foods. Food Quality and Preference 18(2007): 1-12. https:// doi.org/10.1016/j.foodqual.2005.06.007.

Verbeke W. 2004. Consumer acceptance of functional foods: socio-demographic, cognitive, and attitudinal determinants. Food Quality and Preference 16(2005): 45-57. https://doi. org/10.1016/j.foodqual.2004.01.001. 